\title{
Effect of Ohmic Heating on Quality and Storability of Sugarcane Juice
}

\author{
P. Abhilasha* and U.S. Pal
}

Department of Argil. Processing and Food Engineering, College of Agricultural Engineering \& Technology, Orissa University of Agriculture and Technology, Bhubaneswar, Orissa, India

*Corresponding author

\section{A B S T R A C T}

Keywords

Sugarcane, Ohmic heating, Storability, Conventional Heating, Quality

\section{Article Info}

Accepted:

20 December 2017

Available Online:

10 January 2018
Sugarcane juice was analysed for the two different treatments such as ohmic heating and conventional heating. The study analysis showed that the total plate count decreased with severity of ohmic heating treatment which reduced from 6.3 to $3.47 \mathrm{log} \mathrm{cfu} / \mathrm{ml}$ for $90^{\circ} \mathrm{C}$ and 15 min treatment. So observing the PPO inactivation, colour change and microbial reduction of the treated samples into consideration, ohmic heating of sugarcane juice at $70^{\circ} \mathrm{C}$ for $3 \mathrm{~min}$ holding time was found to be optimum. Hence, highest microbial reduction was observed in ohmic heating treatment than conventional heating treatment.

\section{Introduction}

Sugarcane (Saccharum officinarum) is one of the most widely relished beverages of south Asia. It is also known as noble cane, due to its high sucrose content and low fiber content is important in industrial crops of the world. Enzymatic browning is one of the major causes for deleterious changes in the sensory properties of the product thereby limiting its storage for a longer time (Bucheliand Robinson, 1994). Sugarcane juice has been used in the Ayurveda and Unani systems of medicine in India, since time immemorial. Sugarcane extract has displayed a wide range of biological effects including immune stimulation (El-Abasy et al., 2002), anti- thrombosis activity, anti-inflammatory activity, vaccine adjuvant, modulation of acetylcholine release (Barocci et al., 1999).

Conventional heat processing imparts the taste of jaggery and the delicate flavor of juice is adversely affected. Polyphenol oxidase is the major enzyme involved in the discoloration of sugarcane juice which can be improved by heat inactivation of enzyme. Addition of citric acid or ascorbic acid to juice also gave good pleasant dull orange colour to juice. Addition of lemon and ginger followed by pasteurization and preservation with sulphur dioxide also reduced physico-chemical changes during storage of ready-to-serve bottled sugarcane juice. However enzymatic 
browning and spoilage by microorganisms due to the presence of simple sugar after extraction are responsible for its short shelf life. Ohmic heating $(\mathrm{OH})$ has gained wide popularity as an alternative thermal treatment as it causes volumetric heating of the sample which leads to consistent and rapid heat generation especially in liquid foods. The rate of heat generation in $\mathrm{OH}$ is a function of electric field strength applied across the food material (Ramaswamy, Marcotte, Sastry, and Abdelrahim, 2014). Due to short processing times, $\mathrm{OH}$ causes minimum discoloration and maintains the nutritive value of the food (Leizerson and Shimoni, 2005; Wang and Sastry, 2002). This feature makes it one of the most desirable treatments particularly for sugarcane juice; as it contains sensitive flavor components that are easily destroyed at longer treatment times.

\section{Materials and Methods}

\section{Preparation of sugarcane juice}

Fully mature sugarcane stems were procured from the local market of Bhubaneswar. Fresh sugarcane was used for the extraction of sugarcane juice. Sugarcane stems were then washed by running tap water to get sugarcane free from any dust and dirt. The stems were peeled and manually cut into small pieces with the help of stainless steel knife. Sugarcane juice were extracted by motor grinder (Make: Krishna) and filtered through the sieve and muslin cloth to remove the extraneous matterandobtain a clear filtrate which was used for the study.

\section{Application of different preservation techniques}

\section{Conventional heating}

Different lots of sugarcane juices were subjected to pasteurization (at 70,80 and $90^{\circ} \mathrm{C}$ for 5, 10 and $15 \mathrm{~min}$ ), A volume of $50 \mathrm{ml}$ of juice was taken in a beaker and placed in lab scale water bath maintained at the desired temperature (Fig. 1). After the desired temperature of juice was achieved, it was held at that temperature for the desired time duration fresh sugarcane juice was taken as control. Three alternated replicates were conducted for each condition. The treated samples are analysed for PPO inactivation, physio-chemical, microbial and sensory attributes. All the lots of juices were filled and stored in sterilized HDPE bottle for 20 days at refrigeration temperature $\left(4^{0} \mathrm{C}\right)$. The samples were drawn and analyzed for physicochemical, microbiological and sensory attributes at an interval of 5 days.

\section{Ohmic heating}

\section{Development of ohmic heating set up}

Four ohmic heating set up were developed for treatment of the sugarcane juice. Rectangular chambers were fabricated from perplex sheet with different length to obtain different electrical field strengths of 16, 32, 48 and 64 $\mathrm{V} / \mathrm{cm}$. Two stainless steel flat (100x50x5 mm) were used as electrodes and inserted in the groove located at the two ends of the rectangular chamber. The distance between the electrodes were maintained at 14.4, 7.2, 4.8 and $3.6 \mathrm{~cm}$ to obtain electrical field strengths of 16, 32, 48 and $64 \mathrm{~V} / \mathrm{cm}$. A power supply of $230 \mathrm{~V}$ and $50 \mathrm{~Hz}$ was used to carry out the experiment.

\section{Ohmic heating of sugarcane juice}

The ohmic heating of sugarcane juice was carried out at four different electric field strengths and the temperature rise with heating time was recorded. The best set up was used for further ohmic heating study. The sample was placed in the chamber and connected to the electrical circuit. A digital temperature 
indicator was was used to record and maintain the temperature of the sugarcane juice during treatment. The samples were heated and held at 70,80 and $90^{\circ} \mathrm{C}$ for 1,2 and 3 min holding time during ohmic heating (Fig. 2).

The heating time, holding time and total processing time is given in Table 1. The samples were stored in sterilized HDPE bottle for further analysis.

\section{Storage study}

Samples processed by different treatments were packed in sterile HDPE bottle and stored under refrigerated conditions of storage for 20 days. The physico-chemical and microbial parameters of the stored sugarcane juice were conducted at 5 days storage interval for assessment of shelf life by different preservation techniques.

\section{Determination of quality parameters}

\section{Polyphenol oxidase (PPO) enzyme assay}

The assay of the enzyme was carried out as described by Ozoglu and Bayindirli (2002). One $\mathrm{ml}$ of $0.2 \mathrm{~mol} / \mathrm{L}$ Catechol solution was added to mixture of $0.5 \mathrm{ml}$ of sugarcane juice and $2 \mathrm{ml}$ of phosphate buffer $(\mathrm{pH} \mathrm{6.5)}$. The absorbance was measured at $420 \mathrm{~nm}$ at every 1 min interval by spectrophotometer (Make: Systronics; Model: 106). The enzyme activity was estimated from the linear portion of the curve of absorbance v/s time. One unit of PPO activity was defined as 0.001A420/min.

Enzyme activity was expressed in $\mathrm{U} / \mathrm{mL}$ with one unit equivalent to a variation of 0.001 absorbance per minute per $\mathrm{mL}$ of sample. The equation 1 was applied to calculate the enzyme activity:

$$
\operatorname{Activity}(U / m l)=\frac{\left(A b_{\text {sample }}-A b_{\text {blank }}\right)}{0.001 \times t}
$$

Where $A b_{\text {sample }}$ is the sample absorbance; $A b_{\text {blank }}$ is the blank absorbance; and $t$ the incubation time of sample with reagents (min).

The activity of the samples was expressed as $\%$ Residual PPO Activity (RA) as given in Eq. (2):

$$
\% \mathrm{RA}=\frac{\text { Current Enzyme Activity }}{\text { Initial Enzyme Activity }}
$$

\section{Physicochemical tests}

Physico-chemical parameters such as Hunter colour value, total soluble solid (TSS), titrable acidity, reducing sugar content of treated sugarcane juice were performed as determined by AOAC International (AOAC, 2007).

\section{TSS}

The total soluble solids content of sugarcane juice (expressed as ${ }^{\circ}$ Brix) was determined using portable digital refractometer (Make: ATAGO. Model: REF113).

\section{Measurement of color}

Colour of the sugarcane juice samples was measured by colour reader CR-20 (Konica Minolta, INC, Japan). Colorimeter was calibrated using white control sample Coordinates ' $L$ ' represented the lightness of color $(0=$ black; $100=$ white $),-\mathrm{a} /+\mathrm{a}$ greenness or redness, and $-b /+b$ blueness or yellowness. Samples were kept in petri plates and colour value of $\mathrm{L}, \mathrm{a}$ and $\mathrm{b}$ was measured. For each sample, three measurements were taken and averaged. The total color change $(\Delta \mathrm{E})$ was calculated using Eq 3 (Altan et al., 2008). $\mathrm{L}_{0}, \mathrm{a}_{0}$ and $\mathrm{b}_{0}$ are the colour values of control sample.

$$
\Delta \mathrm{E}=\sqrt{(\mathrm{L}-\mathrm{L} 0)^{2}+(\mathrm{a}-\mathrm{a} 0)^{2}+\left(\mathrm{b}-\mathrm{b}_{0}\right)^{2}}
$$




\section{Titrable acidity}

The titratable acidity (expressed as \% citric acid) was determined by titration with $0.1 \mathrm{~N}$ $\mathrm{NaOH}$. It was determined by quantifying the volume of $0.01 \mathrm{~N} \mathrm{NaOH}$ required to raise the $\mathrm{pH}$ value to 8.3 , and expressed as $\mathrm{ml}$ of 0.01 $\mathrm{M} \mathrm{NaOH}$ per $10 \mathrm{ml}$ of juice. About $10 \mathrm{mlof}$ sample was Pipette in to a $250 \mathrm{ml}$ conical flask. It was added about $50 \mathrm{ml}$ of distilled water and few drops of phenopthalin indicator in to the conical flask. It was Titrated against to the $0.1 \mathrm{~N} \mathrm{NaOH}$ up to light pink end point with solution product (Fig. 3).

Eq. wt. of acid $\times$ Titre value $\times$ Normality of $\mathrm{NaOH}$

Acidity, \% = ---------------------- (4)

$10 \times$ vol. of sample taken

\section{Reducing sugar content}

Reducing sugar content was determination by DNS (Dinitro salicylic Acid) method. About $0.5 \mathrm{ml}$ of the sample was taken in a test tube and the volume was equalized to $3 \mathrm{ml}$ with distilled water. $3 \mathrm{ml}$ of DNS reagent was added to it. Then the contents in the test-tube were heated in a boiling water bath for 5mins. When the contents of the tubes were still warm, $1 \mathrm{ml}$ of $40 \%$ Rochelle salt solution was added to it. It was cooled and the absorbance reading was taken at $510 \mathrm{~nm}$. A series of standards was prepared using glucose (0$500 \mathrm{mg}$ ) and plot a graph. The amount of reducing sugar present in the sample was determined from the standard curve.

\section{Microbiological tests}

The sugarcane juice samples was analysed for their commercial sterility. Total Plate Count (TPC) was determined using Nutrient Agar (NA) after incubation, and for $48 \mathrm{~h}$ at $30^{\circ} \mathrm{C}$. Yeast and molds (YMC) were estimated with the help of acidified potato dextrose agar
(PDA). TPC and YMC were counted in series dilution method. Results were expressed as colony forming units per milliliter.

The unit for calculation is CFU $=$ (Number of colony $\times$ dilution factor)/volume plated in $\mathrm{mL}$

\section{Sensory tests}

Sensory evaluation of sugarcane juice processed by different treatments was carried out, using a nine-point hedonic scale, as described by Dutcosky (2013). The attributes like colour, flavour and taste were evaluated by 10 panelists and consumers. The juice was served at a temperature of about $12^{\circ} \mathrm{C}$. The overall acceptability of sugarcane juice was calculated by composite scoring giving 40, 20 and $40 \%$ weightage to colour, flavour and taste score.

\section{Statistical analysis}

The experimental data were analysed by Analysis of variance (ANOVA) using MS EXCEL 2007at 5\% confidence level for comparison.

\section{Results and Discussion}

\section{Effect of different treatments on quality of sugarcane juice}

\section{Conventional heating}

The effect of different processing temperature and treatment time on residual PPO activity (\% RA), colour change, titrable acidiy, reducing sugar content, TSS and total plate count during conventional heating is shown in Table 2. It was observed that residual PPO activity decreased with increase in processing temperature and time ( $p<0.05)$. Highest residual PPO activity was observed at $70^{\circ} \mathrm{C}$ for $5 \mathrm{~min}$, whereas it was found to be less at higher processing temperature of $90^{\circ} \mathrm{C}$. 
However, no significant difference $(\mathrm{p}<0.05)$ was found in the RA of the enzyme at $80^{\circ} \mathrm{C}$ for 10 and $15 \mathrm{~min}$ treatment and $90^{\circ} \mathrm{C}$ for all the time treatment suggesting the development of resistance of the enzyme to inactivation after prolonged exposure to high temperature which had also been reported by Terefe et al., (2010).

Further, the change in colour was more at higher processing temperature and longer treatment time probably due to non-enzymatic browning during thermal treatment. It was observed that reducing sugar content increased significantly $\quad(p<0.05) \quad$ with processing temperature and time. This might be due to the inversion of sugar which resulted in higher reducing sugar content leading to poor keeping quality of the juice. The TA of samples was not changing significantly and the slight increase may be attributed to some biochemical processes that might have been accelerated by the treatment. The increase in TSS was observed with heating temperature and time probably due to evaporation of water due to heat treatment. The total plate count decreased with severity of thermal treatment which reduced from 6.3 to $3.45 \log \mathrm{cfu} / \mathrm{ml}$ at $90^{\circ} \mathrm{C}$ and 15 min treatment.

So keeping PPO inactivation, colour change, reducing sugar content and microbial reduction of the treated samples into consideration, it was recommended for conventional heating of sugarcane juice at 80 ${ }^{0} \mathrm{C}$ for $10 \mathrm{~min}$.

\section{Ohmic heating}

\section{Effect of field strength on temperature rise}

The temperature rise of sugarcane juice during ohmic heating at four electrical field strength is shown in Table 3. It was observed that temperature rise was slow at 16 and $32 \mathrm{~V} / \mathrm{cm}$ and steady at $64 \mathrm{~V} / \mathrm{cm}$. The juice temperature attained $90^{\circ} \mathrm{C}$ at 5,15 and $36 \mathrm{~min}$ when exposed to ohmic heating at 64, 48 and 32 $\mathrm{V} / \mathrm{cm}$, respectively. Frothing of juice occurred during ohmic heating at $64 \mathrm{~V} / \mathrm{cm}$ with instantaneous temperature rise and it was difficult to control. The low heating rate at 16 and $32 \mathrm{~V} / \mathrm{cm}$, resulted in prolonged treatment time which was not desirable due to quality loss. So, it was decided to conduct the ohmic heating of sugarcane juice at electrical field strength of $48 \mathrm{~V} / \mathrm{cm}$. Castro et al., (2004) reported increase in enzymatic activity when exposed to low electric field strengths due to changes in the molecular spacing that accelerated the inter-chain biochemical reactions and suggested the possible use of higher electric field strength of $48 \mathrm{~V} / \mathrm{cm}$ during ohmic heating.

\section{Effect processing conditions on quality of sugarcane juice}

The effect of different processing temperature and time on residual PPO activity (\% RA), colour change, titrable acidiy, reducing sugar content, TSS and total plate count during ohmic heating of sugarcane juice with 48 $\mathrm{V} / \mathrm{cm}$ field strength is shown in Table 4. It was observed that residual PPO activity decreased significantly $(\mathrm{p}<0.05)$ with increase in treatment temperature and processing time during ohmic heating.

The residual PPO activity was less with less colour change in ohmic heated samples treated with $70^{\circ} \mathrm{C}$ for $3 \mathrm{~min}$ holding time. At higher temperature and holding time the colour change was observed to be more. The reducing sugar and titrable acidity were not changing significantly and the slight increase may be attributed to some biochemical processes that might have been accelerated by the treatment. The TSS increased with processing temperature which might be due to evaporation of water by thermal effect during ohmic heating. 
Table.1 Heating time, holding time and total processing time during conventional and ohmic heating treatment

\begin{tabular}{|l|l|l|l|}
\hline Temperature, ${ }^{\mathbf{0}} \mathrm{C}$ & $\begin{array}{l}\text { Heating time } \\
(\mathbf{m i n})\end{array}$ & $\begin{array}{l}\text { Holding time } \\
(\mathbf{m i n})\end{array}$ & $\begin{array}{l}\text { Total processing time } \\
(\mathbf{m i n})\end{array}$ \\
\hline Conventional heating & & & \\
\hline $\mathbf{7 0}$ & 10 & $5,10,15$ & $15,20,25$ \\
\hline $\mathbf{8 0}$ & 12 & $5,10,15$ & $17,22,27$ \\
\hline $\mathbf{9 0}$ & 14 & $5,10,15$ & $19,24,29$ \\
\hline Ohmic heating & & & \\
\hline $\mathbf{7 0}$ & 12 & $1,2,3$ & $13,14,15$ \\
\hline $\mathbf{8 0}$ & 13.5 & $1,2,3$ & $13.5,15.5,16.5$ \\
\hline $\mathbf{9 0}$ & 15 & $1,2,3$ & $16,17,18$ \\
\hline
\end{tabular}

Table.2 Physico-chemical and microbial properties of sugarcane juice treated with conventional heating at different temperature and time

\begin{tabular}{|c|c|c|c|c|c|c|c|}
\hline Temperature, ${ }^{0} \mathrm{C}$ & $\begin{array}{l}\text { Holding } \\
\text { time } \\
\text { (min) }\end{array}$ & RA \% & $\begin{array}{l}\text { Colour } \\
\text { change }\end{array}$ & $\begin{array}{l}\text { Titrable } \\
\text { acidity } \\
(\mathrm{g} / 100 \mathrm{ml})\end{array}$ & $\begin{array}{l}\text { Reducing } \\
\text { sugar } \\
(\mathrm{g} / 100 \mathrm{ml})\end{array}$ & $\begin{array}{l}\text { TSS } \\
\left({ }^{0} \text { Brix }\right)\end{array}$ & $\begin{array}{l}\text { TPC } \\
(\log \text { cfu/ml })\end{array}$ \\
\hline \multirow[t]{3}{*}{70} & 5 & $58.9 \pm 4.1$ & $3.5 \pm 0.2$ & $0.132 \pm 0.003$ & $0.482 \pm 0.005$ & $18.7 \pm 0.3$ & $6.13 \pm 0.09$ \\
\hline & 10 & $55.3 \pm 3.8$ & $3.9 \pm 0.2$ & $0.136 \pm 0.004$ & $0.479 \pm 0.004$ & $19.4 \pm 0.3$ & $5.57 \pm 0.06$ \\
\hline & 15 & $50.1 \pm 3.6$ & $4.2 \pm 0.3$ & $0.136 \pm 0.004$ & $0.475 \pm 0.003$ & $20.7 \pm 0.3$ & $5.04 \pm 0.04$ \\
\hline \multirow[t]{3}{*}{80} & 5 & $51.6 \pm 3.6$ & $4.2 \pm 033$ & $0.136 \pm 0.004$ & $0.483 \pm 0.005$ & $19.6 \pm 0.3$ & $6.08 \pm 0.07$ \\
\hline & 10 & $42.2 \pm 3.2$ & $4.6 \pm 0.4$ & $\mathbf{0 . 1 3 2} \pm 0.003$ & $\mathbf{0 . 4 9 0} \pm 0.006$ & $20.6 \pm 0.4$ & $\mathbf{5 . 0 1} \pm 0.05$ \\
\hline & 15 & $40.1 \pm 2.8$ & $6.2 \pm 0.41$ & $0.131 \pm 0.002$ & $0.524 \pm 0.007$ & $21.9 \pm 0.4$ & $4.81 \pm 0.04$ \\
\hline \multirow[t]{3}{*}{90} & 5 & $38.3 \pm 2.5$ & $8.5 \pm 0.45$ & $0.140 \pm 0.004$ & $0.569 \pm 0.008$ & $20.5 \pm 0.4$ & $5.92 \pm 0.08$ \\
\hline & 10 & $38.0 \pm 2.2$ & $9.1 \pm 0.43$ & $0.136 \pm 0.005$ & $0.572 \pm 0.009$ & $21.4 \pm 0.5$ & $4.34 \pm 0.04$ \\
\hline & 15 & $35.7 \pm 2.1$ & $10.8 \pm 0.5$ & $0.132 \pm 0.003$ & $0.592 \pm 0.009$ & $22.7 \pm 0.5$ & $3.45 \pm 0.04$ \\
\hline Control & & & & 0.130 & 0.460 & 18.1 & 6.30 \\
\hline
\end{tabular}

Table.3 Temperature profile of sugarcane juice at different electrical field strength

\begin{tabular}{|c|c|c|c|c|}
\hline \multirow[t]{2}{*}{ Time (min) } & \multicolumn{4}{|c|}{ Electric field strength, V/cm } \\
\hline & 16 & 32 & 48 & 64 \\
\hline 5 & 27 & 40 & 41 & 90 \\
\hline 10 & 28 & 44 & 53 & \\
\hline 15 & 39 & 52 & 90 & \\
\hline 20 & 41 & 57 & & \\
\hline 25 & 45 & 67 & & \\
\hline 30 & 49 & 75 & & \\
\hline 35 & 52 & 88 & & \\
\hline 36 & 54 & 90 & & \\
\hline 40 & 57 & & & \\
\hline 45 & 59 & & & \\
\hline 50 & 62 & & & \\
\hline 55 & 65 & & & \\
\hline 60 & 67 & & & \\
\hline 65 & 70 & & & \\
\hline
\end{tabular}


Table.4 Physico-chemical and microbial properties of sugarcane juice at different processing temperature and time duringohmic heating at $48 \mathrm{~V} / \mathrm{cm}$

\begin{tabular}{|c|c|c|c|c|c|c|c|}
\hline $\begin{array}{l}\text { Ohmic } \\
\text { heating } \\
\text { Temperature } \\
\left({ }^{0} \mathrm{C}\right)\end{array}$ & $\begin{array}{l}\text { Holding } \\
\text { time } \\
\text { (min) }\end{array}$ & $\mathbf{R A} \%$ & $\begin{array}{l}\text { Colour } \\
\text { change }\end{array}$ & $\begin{array}{l}\text { Titrable } \\
\text { acidity } \\
(\mathrm{g} / 100 \mathrm{ml})\end{array}$ & $\begin{array}{l}\text { Reducing } \\
\text { sugar } \\
(\mathrm{g} / 100 \mathrm{ml})\end{array}$ & $\begin{array}{l}\text { TSS } \\
\left({ }^{0} \text { Brix }\right)\end{array}$ & $\begin{array}{l}\text { TPC } \\
(\log \\
\text { cfu/ml) }\end{array}$ \\
\hline \multirow[t]{3}{*}{70} & 1 & $69.1 \pm 2.3$ & $3.2 \pm 0.2$ & $0.136 \pm 0.004$ & $0.463 \pm 0.004$ & $19.2 \pm 0.3$ & $4.70 \pm 0.009$ \\
\hline & 2 & $49.42 \pm 2.2$ & $3.6 \pm 0.2$ & $0.132 \pm 0.002$ & $0.468 \pm 0.005$ & $19.4 \pm 0.31$ & $4.61 \pm 0.008$ \\
\hline & 3 & $21.4 \pm 2.1$ & $4.2 \pm 0.3$ & $\mathbf{0 . 1 3 0} \pm 0.001$ & $0.462 \pm 0.004$ & $19.7 \pm 0.4$ & $4.25 \pm 0.003$ \\
\hline \multirow[t]{3}{*}{80} & 1 & $42.0 \pm 2.2$ & $6.3 \pm 0.4$ & $0.138 \pm 0.009$ & $0.479 \pm 0.005$ & $19.5 \pm 0.33$ & $4.31 \pm 0.003$ \\
\hline & 2 & $33.0 \pm 2.3$ & $6.6 \pm 0.4$ & $0.134 \pm 0.003$ & $0.485 \pm 0.006$ & $19.8 \pm 0.4$ & $4.14 \pm 0.002$ \\
\hline & 3 & $19.7 \pm 2.1$ & $7.0 \pm 0.4$ & $0.130 \pm 0.001$ & $0.487 \pm 0.006$ & $20.1 \pm 0.5$ & $3.96 \pm 0.002$ \\
\hline \multirow[t]{3}{*}{90} & 1 & $32.2 \pm 2.3$ & $7.6 \pm 0.5$ & $0.134 \pm 0.003$ & $0.500 \pm 0.007$ & $19.4 \pm 0.32$ & $4.12 \pm 0.003$ \\
\hline & 2 & $18.8 \pm 2.0$ & $8.9 \pm 0.5$ & $0.134 \pm 0.003$ & $0.510 \pm 0.008$ & $20.1 \pm 0.5$ & $3.66 \pm 0.007$ \\
\hline & 3 & $16.3 \pm 2.0$ & $10.8 \pm 0.6$ & $0.137 \pm 0.007$ & $0.540 \pm 0.009$ & $20.5 \pm 0.5$ & $3.47 \pm 0.007$ \\
\hline Control & & & & $0.130 \pm 0.008$ & $0.460 \pm 0.007$ & $18.1 \pm 0.4$ & $6.30 \pm 0.009$ \\
\hline
\end{tabular}

Table.5 Titrable acidity $(\mathrm{g} / 100 \mathrm{ml})$ of sugarcane juice treated with Different methods during storage

\begin{tabular}{|l|l|l|l|l|l|} 
Treatments & \multicolumn{2}{l}{ Storage period, days } & & \\
& $\mathbf{0}$ & $\mathbf{5}$ & $\mathbf{1 0}$ & $\mathbf{1 5}$ & $\mathbf{2 0}$ \\
\hline Control & $0.13 \pm 0.004$ & $0.55 \pm 0.004$ & $0.86 \pm 0.005$ & $1.13 \pm 0.008$ & $1.43 \pm 0.008$ \\
\hline CH & $0.132 \pm 0.003$ & $0.24 \pm 0.005$ & $0.47 \pm 0.004$ & $0.86 \pm 0.008$ & $1.14 \pm 0.008$ \\
\hline OH & $0.130 \pm 0.004$ & $0.23 \pm 0.005$ & $0.36 \pm 0.004$ & $0.56 \pm 0.005$ & $0.78 \pm 0.004$ \\
\hline
\end{tabular}

Table.6 Reducing sugar content $(\mathrm{g} / 100 \mathrm{ml})$ of sugarcane juice during storage

\begin{tabular}{|l|l|l|l|l|l|} 
Treatments & \multicolumn{5}{l}{ Storage period, days } \\
& $\mathbf{0}$ & $\mathbf{5}$ & $\mathbf{1 0}$ & $\mathbf{1 5}$ & $\mathbf{2 0}$ \\
\hline Control & $0.460 \pm 0.004$ & $0.48 \pm 0.005$ & $0.56 \pm 0.006$ & $0.60 \pm 0.007$ & $0.66 \pm 0.009$ \\
\hline CH & $0.490 \pm 0.005$ & $0.50 \pm 0.007$ & $0.52 \pm 0.003$ & $0.54 \pm 0005$ & $0.57 \pm 0.007$ \\
\hline OH & $0.462 \pm 0.004$ & $0.48 \pm 0.005$ & $0.49 \pm 0.005$ & $0.51 \pm 0.004$ & $0.53 \pm 0.004$ \\
\hline
\end{tabular}

Table.7 Colour change value of sugarcane during storage

\begin{tabular}{|l|l|l|l|l|l|} 
Treatments & \multicolumn{5}{l}{ Storage period, days } \\
& $\mathbf{0}$ & $\mathbf{5}$ & $\mathbf{1 0}$ & $\mathbf{1 5}$ & $\mathbf{2 0}$ \\
\hline Control & & $4.6 \pm 0.3$ & $5.8 \pm 0.38$ & $6.4 \pm 0.47$ & $7.5 \pm 0.49$ \\
\hline CH & $4.6 \pm 0.2$ & $6.5 \pm 0.33$ & $8.9 \pm 0.39$ & $13.4 \pm 0.46$ & $18.2 \pm 0.5$ \\
\hline OH & $4.2 \pm 0.2$ & $6.2 \pm 0.33$ & $8.1 \pm 0.41$ & $11.2 \pm 0.47$ & $14.7 \pm 0.5$ \\
\hline
\end{tabular}


Table.8 Total plate count (log $\mathrm{cfu} / \mathrm{ml})$ of sugarcane juice during storage

\begin{tabular}{|l|l|l|l|l|l|} 
Treatments & \multicolumn{4}{l}{ Storage period, days } \\
& $\mathbf{0}$ & $\mathbf{5}$ & $\mathbf{1 0}$ & $\mathbf{1 5}$ & $\mathbf{2 0}$ \\
\hline Control & $6.30 \pm 0.06$ & $6.32 \pm 0.07$ & $6.56 \pm 0.079$ & $6.98 \pm 0.08$ & $7.23 \pm 0.088$ \\
\hline CH & $5.01 \pm 0.065$ & $5.23 \pm 0.076$ & $5.60 \pm 0.079$ & $5.81 \pm 0.082$ & $5.98 \pm 0.089$ \\
\hline OH & $4.25 \pm 0.064$ & $4.45 \pm 0.077$ & $4.80 \pm 0.078$ & $5.01 \pm 0.084$ & $5.11 \pm 0.089$ \\
\hline
\end{tabular}

Fig.1 Conventional heating of sugarcane juice in water bath

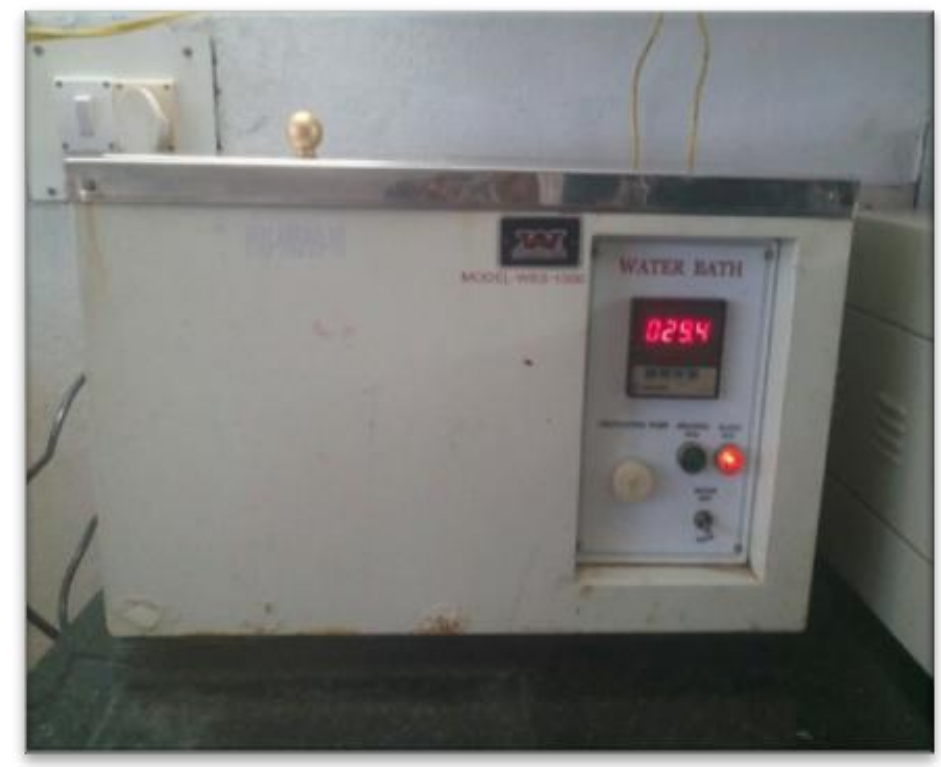

Fig.2 Ohmic heating set up

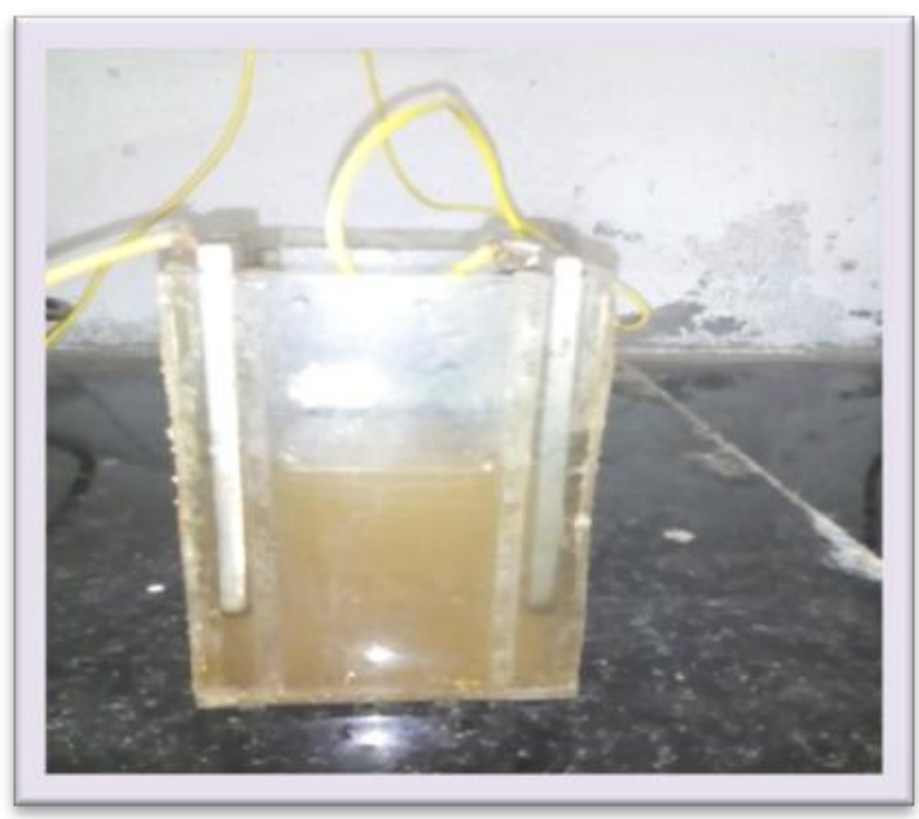


Fig.3 Change in titrable acidity of sugarcane juice processed

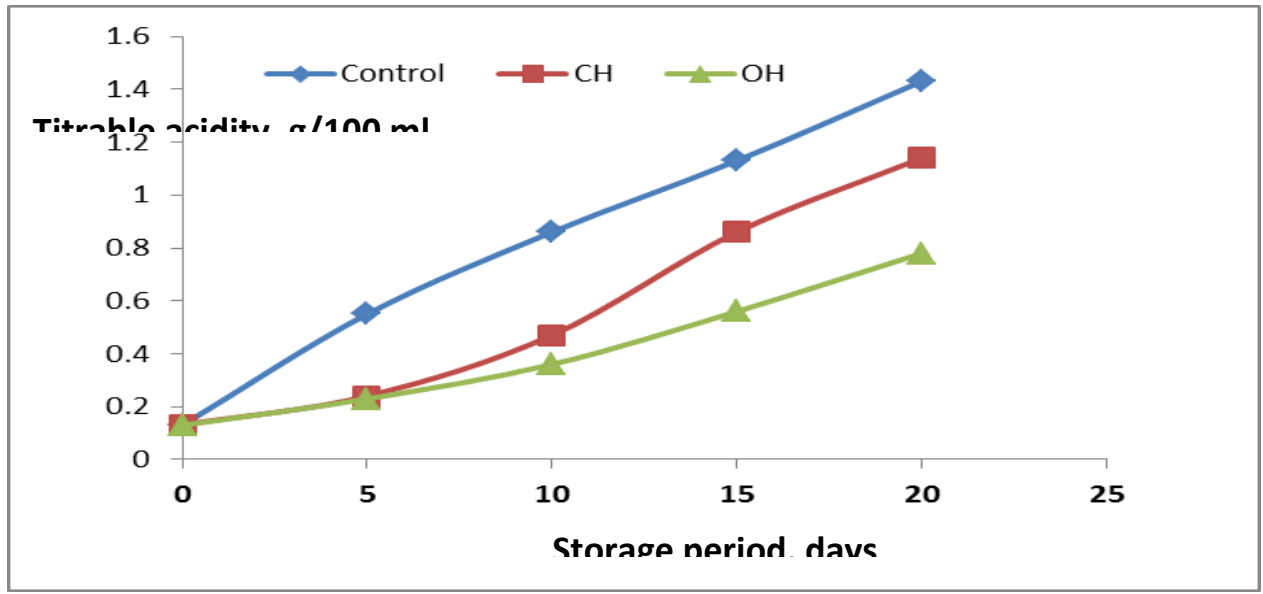

Fig.4 Change in reducing sugar of sugarcane juice processed by different treatments during storage

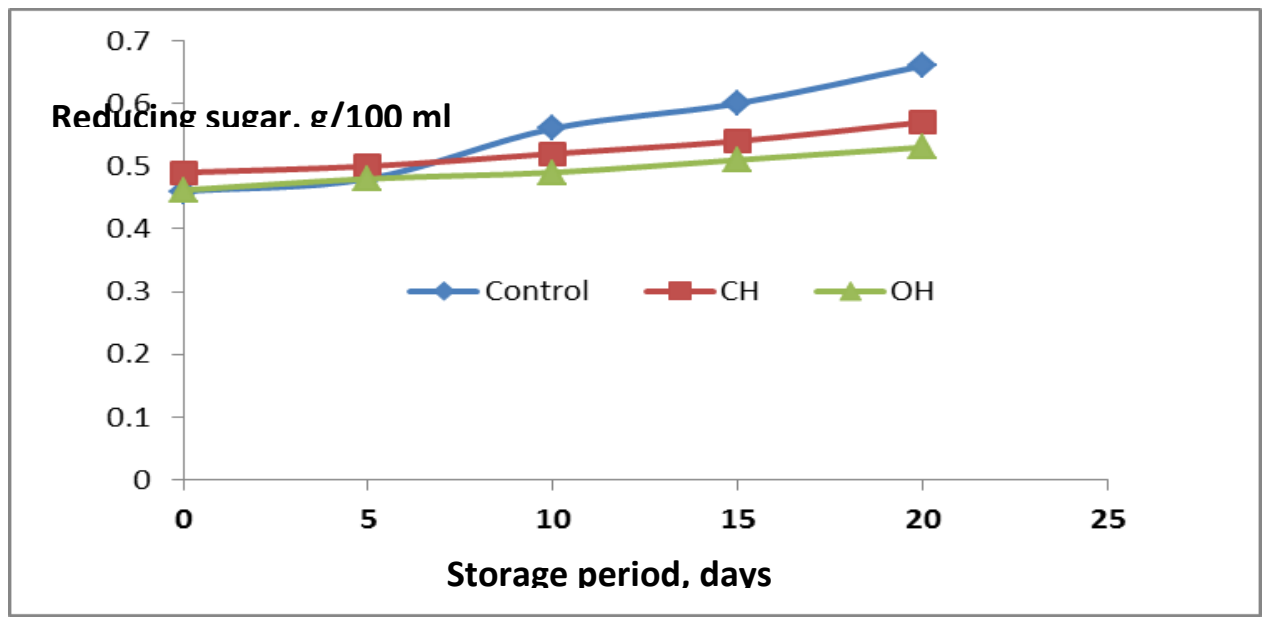

Fig.5 Change in Change in colour of sugarcane juice processed by different treatments during storage

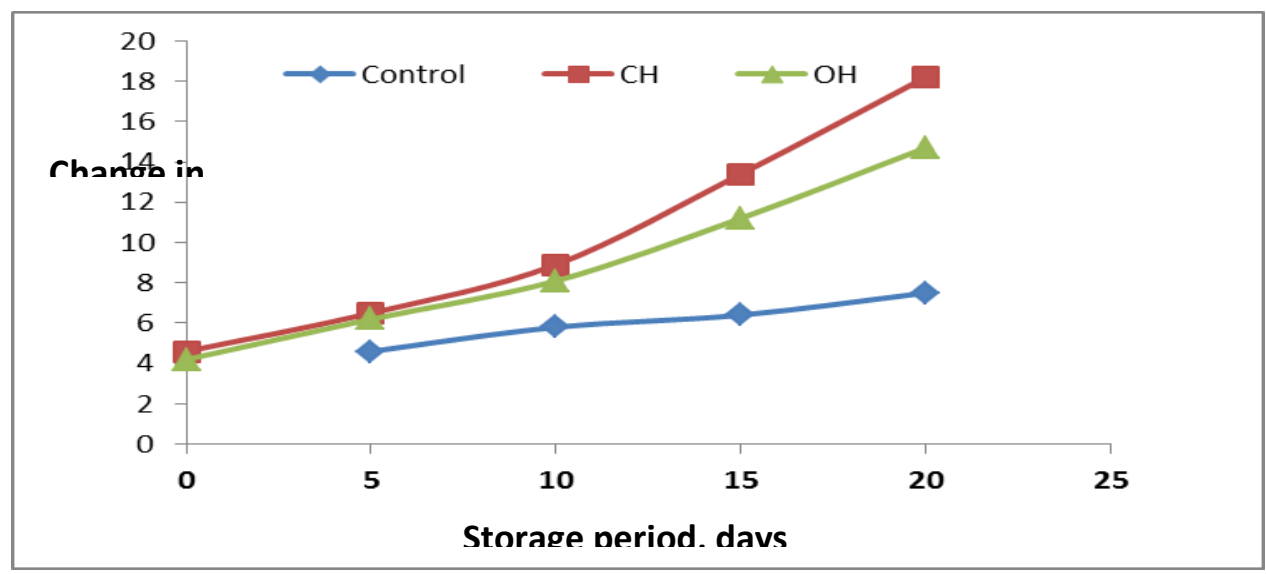


Fig.6 Change in microbial load of sugarcane juice processed during storage

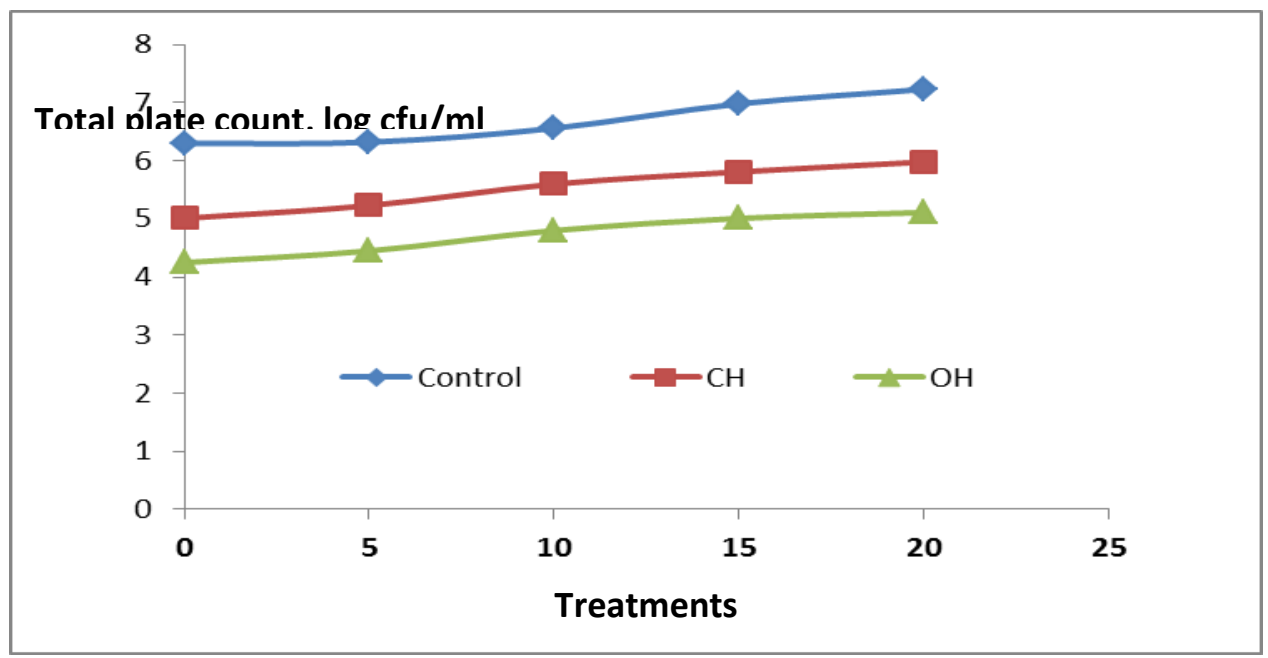

The total plate count decreased with severity of ohmic heating treatment which reduced from 6.3 to $3.47 \mathrm{log} \mathrm{cfu} / \mathrm{ml}$ for $90^{\circ} \mathrm{C}$ and 15 min treatment. Saxena et al., (2016) reported that higher field strength of $48 \mathrm{~V} / \mathrm{cm}$ resulted in a significant reduction in \% RA and higher degree of microbial reduction probably due to the combined effect of heat as well as electric current.

So keeping PPO inactivation, colour change and microbial reduction of the treated samples into consideration, ohmic heating of sugarcane juice at $70{ }^{0} \mathrm{C}$ for $3 \mathrm{~min}$ holding time was found to be optimum.

\section{Storage study}

The sugarcane juice treated with different methods at optimum dose was stored in sterile HDPE bottle under refrigerated condition. The quality parameters such as titrable acidity, reducing sugar, colour change and microbial load of the samples were determined after 5 days interval.

\section{Titrable acidity}

The TA of sugarcane juice increased significantly $(\mathrm{p}<0.05)$ with storage period.
The increase in TA of ohmic heated sample from 0.13 to $0.78 \mathrm{~g} / 100 \mathrm{ml}$ was less compared to conventional heating treatment indicating better storability (Table 5). The acidity of ohmic heated juice increased to 0.37 after 10 days of storage under ambient condition with acceptable odour.

\section{Reducing sugar}

The RS content for untreated juice increased significantly $(\mathrm{p}<0.01)$ from 0.46 to 0.66 after 20 days of storage (Table 6 and Fig. 4). The increase was less in ohmic heated samples. Increase in reducing sugar during storage of sugarcane juice was also reported by Saxena et al., (2016). The increase in reducing sugar during storage was probably due to the action of dextransucrase on sucrose releasing RS molecule.

\section{Change in colour}

The change in colour during storage of sugarcane juice treated with different processing conditions is given in Table 7. The colour change was found to be more in ohmic heating samples as compared to conventionally heated samples (Fig. 5). The higher colour change in ohmic heated samples 
was probably due to non-enzymatic browning and formation of viscous jelly like substance called dextran by the action of enzyme.

\section{Microbial load}

The microbiology parameters were investigated to observe the quality ohmic heated and conventionaly heated sugarcane juice samples. Total plate count (TPC) value increased significantly $(\mathrm{p}<0.05)$ with storage period. The increase was highest in control sample and lowest in ohmic heated sample (Fig. 6). The microbial count in control sample increased from $6.3 \pm 0.06$ to $7.23 \pm 0.088$ after 20 days of storage under refrigerated storage (Table 8 ). Ohmic heated sample could be stored up to 10 days having TPC value less than $10^{5}$. The mechanism of microbial destruction by heat is well known and higher degree of inactivation by $\mathrm{OH}$ treatment was due to the combined effect of heat as well as electric current. Microbial inactivation by electric field has been reported to be majorly by electroporation (Tsong, 1991) but some researchers have also suggested the formation of microbicidal agents such as chlorine, hydrogen peroxide etc., due to electric discharge in liquid media, that alter the DNA and cytoplasmic activity of the cells (Hulsheger, Potel, and Niemann, 1981).

Highest residual PPO activity was observed at $70^{0} \mathrm{C}$ for $5 \mathrm{~min}$, whereas it was found to be less at higher processing temperature of $90^{\circ} \mathrm{C}$. The change in colour was more at higher processing temperature and longer treatment time. Heating sugarcane juice to $80{ }^{0} \mathrm{C}$ and holding for $10 \mathrm{~min}$ was found to be the optimum condition in conventional heating. Frothing of juice occurred during ohmic heating at $64 \mathrm{~V} / \mathrm{cm}$ with instantaneous temperature and low heating rate at 16 and 32 $\mathrm{V} / \mathrm{cm}$, resulted in prolonged treatment time. Electrical field strength of $48 \mathrm{~V} / \mathrm{cm}$ was found to be suitable for ohmic heating of sugarcane juice. PPO activity decreased significantly with increase in treatment temperature and processing time during ohmic heating. The reducing sugar and titrable acidity were not changing significantly during ohmic heating. At higher temperature and holding time the colour change was observed to be more. Ohmic heating of sugarcane juice at $70{ }^{0} \mathrm{C}$ for 3 min holding time was found to be optimum. From the above study, it could be concluded that ohmic heating of sugarcane juice at $70^{\circ} \mathrm{C}$ for $3 \mathrm{~min}$ holding time with $48 \mathrm{~V} / \mathrm{cm}$ electrical field strength resulted in higher PPO inactivation and microbial reduction which could be stored safely up to 10 days under refrigerated storage condition with some compromise in the colour of the juice.

\section{References}

Altan, A.; McCathy, K.L.; Maskan, M. Twinscrew extrusion of barley-grape pomacebelnds: extrudate characteristics and determination of optimum processing conditions. Journal of Food Engineering, v.89, p.24-32, 2008

AOAC. 2007. Official methods of analysis (16 ed.). Washington, DC: Association of Official Analytical Chemists.

Assiry, A., Sastry, A. K., and Samarnayake, C. 2003. Degradation kinetics of ascorbic acid during ohmic heating with stainless steel electrodes. Journal of Applied Electrochemistry, 33, 187e196.

Barba, A. A., Calabretti, A., d'Amore, M., Piccinelli, A. L., and Rastrelli, L. 2008. Phenolic constituents levels in cv. Agria potato under microwave processing. LWT- Food Science and Technology, 41(10), 1919-1926.

Barocci, S., Re, L., Capotani, C., Vivani, C., Ricci, M., Rinaldi, L., et al., 1999. Effects if some extracts on the acetylcholine release at the mouse 
neuromuscular joint. Pharmacological Research, 39, 239-245.

Carolyn S. Bucheli, Simon P. Robinson. Contribution of Enzymic Browning to Color in Sugarcane Juice 1994. J. Agric. Food Chem., 1994, 42 (2), pp 257-261

Castro, I., Macedo, B., Teixeira, J. A., and Vicente, A. A. 2004. The effect of electric field on important foodprocessing enzymes: comparison of inactivation kinetics under conventional and ohmic heating. Journal of Food Science, 69(9), 696-701.

Chauhan, O. P., Singh, D., Tyagi, S. M., and Balyan, D. K. 2007. Studies on preservation of sugarcane juice. International Journal of Food Properties, 5(1), 217-229.

Despite the problems of electrochemical degradation associated, $\mathrm{OH}$ has been successfully studied for its use in preheating, blanching, and extraction (Lakkakula, Lima, and Walker, 2004; Leizerson and Shimoni, 2005.)

Eissa, H. A., Shehata, A. N., Ramadan, M. T., and Ali, H. S. 2010. Preservation of sugarcane juice by canning, effect of thermal and chemical pre-treatments on the enzymatic browning of sugarcane juice. Journal of American Science, 6(9).

El-Abasy, M., Motobu, M., Na, K. J., Sameshina, T., Koge, K., Onodera, T., et al., 2002. Immunostimulating and growth promoting effects of sugarcane extracts (SCE) in chickens. Journal of Veterinary Medical Science, 64, 10611063

El-Abasy, M., Motobu, M., Na, K. J., Shimura, K., Nakamura, K., Koge, K., et al., 2003. Protective effect of sugarcane ectracts (SCE) on Eimeriatenella infections in chickens. Journal of Veterinary Medical Science, $65,865-871$.
Huelin, F. E. 1953. Studies on the anaerobic decomposition of ascorbic acid. Food Research, 18, 633-639.

Hulsheger, H., Potel, J., and Niemann, E. G. 1981. Killing of bacteria with electric pulses of high field strength. Radiation and Environmental Biophysics, 20, 5365.

Icier, F. 2005. Alternative heating method in food processing-Ohmic heating. Gida (Food), 30(2), 139-143.

Icier, F., Yildiz, H., and Baysal, T. 2008. Polyphenoloxidase deactivation kinetics during ohmic heating of grape juice. Journal of Food Engineering, 85, 410417.

Khare, A., Lal, A., Singh, A., and Singh, A. 2012. Shelf lif enhancement of sugarcane juice. Croatian Journal of Food Technology, Biotechnology and Nutrition, 7(3), 179-183.

Lakkakula, N. R., Lima, M., and Walker, T. 2004. Rice bran stabilization and rice bran oil extraction using ohmic heating. Bioresource technology, 92, 157-161.

Leathers, T. D. 2002. Dextran. In E. J. Vandamme, S. De Baets, and A. Steinbuchel (Eds.), Polysaccharides I: Polysaccharides from prokaryotes: Vol. 5. Biopolymers (pp. 299-321). Weinheim: Wiley-VCH.

Leizerson, S., and Shimoni, E. 2005. Effect of ultra-high temperature continuous ohmic heating treatment on fresh orange juice. Journal of Agriculture and Food Chemistry, 53, 3519-3524.

Leizerson, S., E. Shimoni Effect of ultra-high temperature continuous ohmic heating treatment on fresh orange juice Journal of Agriculture and Food Chemistry, 53 (2005), pp. 3519-3524

Lima, M., and Sastry, S. K. 1999. The effects of ohmic frequency on hot-air drying rate and juice yield. Journal of Food Engineering, 41, 115-119. 
Lo, D. Y., Chen, T. H., Chien, M. S., Koge, K., Hosono, A., Kaminogawa, S., et al., 2005. Effects of sugarcane extract on modulation of immunity in pigs. Journal of Veterinary Medical Science, 67(6), 591-597

Mao, L. C., Yong, Q., and Fei, Q. 2007. Maintaining the quality of sugarcane juice with blanching and ascorbic acid. Food Chemistry, 104(2), 740-745.

Moreira, M., Ponce, A., Valle, C., and Roura, S. 2006. Ascorbic acid retention< microbial growth and sensory acceptability of lettuce leaves subjected to mild heat shocks. Journal of Food Science, 71(2), 188-192.

Naessens, M., Cerdobbel, A., Soetart, W., and Vandamme, E. J. 2005. Leuconostoc dextransucrase and dextran: production, properties and applications. Journal of Chemical Technology and Biotechnology, 80, 845-860.

Ohshima, T., Tamura, T., and Sato, M. 2007. Influence of pulsed electric field on various enzyme activities. Journal of Electrostatistics, 65(3), 156-161.

Ozoglu, H., and Bayindirli, A. 2002. Inhibition of enzymic browning in cloudy apple juice with anti-browning agents. Food Control, 13, 213-221.

Ramaswamy, H. S., Marcotte, M., Sastry, S., and Abdelrahim, K. 2014. Ohmic heating in food processing. CRC press. International Standard Book Number: 13: 978-1-4200-7109-2.

Rao, P. V. K. J., Das, M., and Das, S. K. 2007. Jaggery- a traditional Indian sweetner. Indian Journal of Traditional Knowledge, 6(1), 95-102.
Rivas, A., Rodrigo, D., Martinez, A., Barbosa-Canovas, G. V., and Rodrigo, M. 2006. Effect of PEF and heat pasteurization on the physicalechemical characteristics of blended orange and carrot juice. LWT- Food Science and Technology, 39, 1163-1170.

Sangeeta, Hathan, B. S., and Khatkar, B. S. 2013. Studies on stability of sugarcane juice blended with anola juice at refrigerated and room temperature. International Journal of Agriculture and Food Science Technology, 4(10), 10271036.

Singh, S., Gaikwad, K., and More, P. K. 2014. Spoilage of sugarcane Juice a problem in sugarcane industry- A review. International Journal of Agricultural Engineering, 7(1), 259263.

Sneh, S., Chaturvedi, A., Kuna, A., and Dhanlakshmi, K. 2012. Preservation of sugarcane juice using hurdle technology. Sugar Technology, 14(1), 26-39.

Terefe, N. S., Yang, Y. H., Knoerzer, K., Buckow, R., and Versteeg, C. 2010. High pressure and thermal inactivation kinetics of polyphenol oxidase and peroxidase in strawberry puree. Innovative Food Science and Emerging Technologies, 11, 52-60.

Tsong, T. Y. 1991. Electroporation of cell membranes. Biophysics Journal, 60, $297 \mathrm{e} 306$.

Wang, W. C., and Sastry, S. K. 2002. Effects of moderate electrothermal treatments on juice yield from cellular tissue. Innovative Food Science and Emerging Technologies, 3, 371-377.

\section{How to cite this article:}

Abhilasha, P. and Pal, U.S. 2018. Effect of Ohmic Heating on Quality and Storability of Sugarcane Juice. Int.J.Curr.Microbiol.App.Sci. 7(01): 2856-2868.

doi: https://doi.org/10.20546/ijcmas.2018.701.340 